\title{
A systematic scoping review of the impacts of community food production initiatives in Kenya, Cameroon, and South Africa
}

\author{
Gráinne B Hutton', Anna Brugulat-Panés², Divya Bhagtani², Camille Maadjhou Mba ${ }^{3}$ Jack M Birch², Hueyjong Shih', \\ Kufre Okop ${ }^{4}$, Monica Muti ${ }^{5}$ Pamela Wadende ${ }^{6}$, Lambed Tatah ${ }^{2}$, Ebele Mogo ${ }^{2}$, Leonor Guariguata ${ }^{7}$, Nigel Unwin ${ }^{8}$ \\ ${ }^{1}$ Department of Public Health and Primary Care, Cambridge Institute of Public Health, University of Cambridge, Cambridge, UK, ${ }^{2}$ MRC Epidemiology \\ Unit, University of Cambridge, Cambridge, UK, ${ }^{3}$ MRC Epidemiology Unit, University of Cambridge, Cambridge, UK; Department of Public Health, \\ Faculty of Medicine and Biomedical Sciences, University of Yaoundé 1, Yaoundé, Cameroon, ${ }^{4}$ Department of Human Biology, Faculty of Health \\ Sciences, University of Cape Town, South Africa, ${ }^{5}$ MRC-Wits Developmental Pathways for Health Research Unit (DPHRU), University of the \\ Witwatersrand, Johannesburg, South Africa, ${ }^{6}$ chool of Education and Human Resource Development (SEDHURED) Kisii University, Kenya, ${ }^{7}$ Faculty of \\ Medical Sciences, University of the West Indies, Barbados, ${ }^{8}$ MRC Epidemiology Unit, University of Cambridge, Cambridge, UK; European Centre for \\ Environment and Human Health, University of Exeter, Exeter, UK \\ Keywords: community food production initiatives, environmental health, food production, food security, south africa, cameroon, kenya \\ https://doi.org/10.29392/001c.19468
}

\section{Journal of Global Health Reports}

Vol. 5, 2021

\section{Background}

Even before the COVID-19 pandemic, one in two people in Africa were food insecure. The burden of malnutrition remains high (e.g. childhood stunting, anaemia in women of reproductive age) or are increasing (e.g. overweight and obesity). A range of coordinated actions are required to improve this situation, including increasing local food production and consumption. The aim of this review was to provide a systematic and comprehensive overview of recently published research into the health, social, economic, and environmental impacts of community food production initiatives (CFPIs) in Kenya, Cameroon and South Africa.

\section{Methods}

We searched eight electronic databases covering health, social, environmental, economic and agricultural sciences. Primary research studies published from 1 January 2014 to 31 December 2018 were considered. Data on geographic location, study design, type of CFPI and the impacts assessed were abstracted from eligible articles.

\section{Findings}

We identified 4828 articles, 260 of which required full-text review and 118 met our eligibility criteria. Most research was conducted in Kenya (53.4\%) and South Africa (38.1\%). The categories of CFPIs studied were (in order of decreasing frequency): crop farming, livestock farming, unspecified farming, fisheries, home / school gardens, urban agriculture, and agroforestry. The largest number of studies were on the economic and environmental impacts of CFPIs, followed by their health and social impacts. The health impacts investigated included food security, nutrition status and dietary intake. One study investigated the potential impact of CFPIs on non-communicable diseases. Over $60 \%$ of studies investigated a single category of impact. Not one of the studies explicitly used a theoretical framework to guide its design or interpretation.

\section{Conclusions}

Our findings on research studies of CFPIs suggest the need for a greater focus on interdisciplinary research in order to improve understanding of the relationships between their health, environmental, economic, and social impacts. Greater use of explicit theoretical frameworks could assist in research design and interpretation, helping to ensure its relevance to informing coordinated intersectoral interventions and policy initiatives.

Diet, nutrition and food insecurity in Sub-Saharan Africa remain major public health concerns, with its people being some of the most nutritionally insecure in the world. ${ }^{1}$ Factors compounding the risk of malnutrition and poor health are conflict, climate variability, poor infrastructure, and a dietary transition towards processed and ultra-processed foods that are energy dense as well as high in refined sugars, saturated fats, and salt. ${ }^{2}$ This shift in dietary patterns, to- 
gether with a decrease in physical activity, contribute to a rise in overweight and obesity that drives an increase in non-communicable diseases (NCDs) such as diabetes, cardiovascular disease and certain types of cancer. ${ }^{3}$ A shift in eating patterns, often attributed to urbanization and unhealthy lifestyles, frequently implies foods which are not meeting micronutrient needs and are driving what is known as a triple burden of malnutrition (TBM) - the coexistence of undernutrition, overnutrition and micronutrient deficiency. 4,5

The global burden of disease attributable to diet and nutritional status is disproportionately greater in low-and middle-income countries (LMICs). ${ }^{3}$ The World Health Organization (WHO) estimates that in Africa, 27\% of adults aged over 20 years are overweight and $8.0 \%$ are obese. ${ }^{6}$ At the same time, hunger is mounting in almost all African sub regions, making it the region with the highest prevalence of undernourishment at nearly $20 \% .^{1}$ Almost one in three (30\%) children in Africa aged under 5 show evidence of stunting of growth as a result of poor nutrition. In women of reproductive age, over a third (38\%) have anaemia. ${ }^{7}$

Associated with these high rates of malnutrition are high levels of food insecurity, and even before COVID-19 these levels were increasing. ${ }^{8}$ In 2018 it is estimated that one in five $(21.5 \%)$ Africans were severely food insecure and one in two $(52.5 \%)$ were moderately or severely food insecure. ${ }^{8}$ Climate change, conflict and economic downturns are core underlying drivers of food insecurity. ${ }^{8}$ Sadly, the impact of COVID-19 is expected to add substantially to the numbers of people experiencing food insecurity. Indeed, the World Food Programme warns that those suffering from acute hunger worldwide could double. ${ }^{9}$ Food shortages have been intensified by the lockdown measures and restrictions on trade flow. The impact on food systems has disproportionately affected the African continent. ${ }^{9}$

Improving food security and decreasing the burdens of malnutrition in African countries requires coordinated actions across the food system. One broad category of action is supporting increased local food production and consumption, not only as a means to improve food security and nutrition but also for other potential benefits, including economic, social and environmental.

The systematic scoping review reported in this paper has been undertaken as part of a programme of work into the upstream determinants of, and potential population level interventions to improve, diet and physical activity in Africa and the Caribbean. The aim of this review is to provide a systematic and comprehensive overview of the published evidence on the health, social, economic and environmental impacts of community food production initiatives (CFPIs) in Kenya, Cameroon and South Africa. In meeting this aim, it is intended that the review will help to inform further research, including new interrogation of the published literature, such as through full systematic reviews, and new primary research. This review complements and builds on the methodology of a similar systematic scoping review of research conducted in Small Island Developing States (SIDS). ${ }^{10}$

\section{METHODS}

We followed the Preferred Reporting Items for Systematic Reviews and Meta-Analysis (PRISMA) guidance for scoping reviews (Online Supplementary Document, Appendix A). ${ }^{11}$ As appropriate for a scoping review, the protocol (Online Supplementary Document, Appendix B) was developed iteratively, informed by the results of initial literature searches, consultation with the wider project team and lessons learnt from previous work. ${ }^{10}$

\section{KEY TERMS AND DEFINITIONS}

In accordance with the NOVA classification criteria and in line with the review undertaken in SIDS, CFPIs were defined as approaches to improving food and nutrition security that are (a) owned and managed locally; and (b) produce either fresh or minimally-processed foods for local consumption. This definition includes agriculture of all types (livestock, crop, etc), home or backyard gardening, aquaculture and fishing. ${ }^{10,11}$

\section{CHOICE OF COUNTRIES}

The African countries chosen as the focus for this scoping review work are part of the Global Diet and Activity (GDAR) network, which is a global health partnership whose overall goal is to identify and intervene on the upstream determinants non-communicable diseases. ${ }^{12}$ GDAR is coordinated from the University of Cambridge, UK, with partners in Cameroon, Kenya and South Africa. GDAR also includes partners in the Caribbean, and as part of a related project a similar systematic scoping review of studies on the impacts of CFPIs in Small Island Developing States was undertake. ${ }^{10}$

\section{IDENTIFYING STUDIES}

A search was conducted from 1 to 6 May 2019 in the following databases: MEDLINE (via PubMed); EMBASE; CINAHL; Web of Science for: Conference Proceedings Citation Index, Science Citation Index Expanded, and ISI (Science Citation Index); SCOPUS; ASSIA (Applied Social Sciences Index and Abstracts); Econlit; AGRIS (hosted by FAO); PubAg (United States Department of Agriculture); AFROLIB (WHO Regional Office Database for Africa). The search was not restricted by language, but it excluded articles published before January 2014 and after December 2018. This timeframe was informed by our interest in the current status of published research in this area, and a pilot study was conducted to better understand the specificity of the criteria, observe any potential discrepancies between screeners and better understand the approximate number of screeners needed to complete both title and abstract and full text screening. A description of the pilot study which informed the search strategy is listed in Online Supplementary Document, Appendix C.

\section{STUDY SELECTION AND INCLUSION EXCLUSION CRITERIA}

Citations identified by the database search were down- 
Table 1: Inclusion and exclusion criteria

\begin{tabular}{|l|l|l|}
\hline Criteria & Inclusion & Exclusion \\
\hline Study type & Primary research & $\begin{array}{l}\text { Non-primary research, including systematic reviews } \\
\text { and meta-analyses }\end{array}$ \\
\hline $\begin{array}{l}\text { Country of } \\
\text { research }\end{array}$ & Cameroon (Cameroun), Kenya and/or South Africa & $\begin{array}{l}\text { All except Cameroon (Cameroun), Kenya and/or South } \\
\text { Africa }\end{array}$ \\
\hline Outcome & $\begin{array}{l}\text { Study examines health, social or economic impact of } \\
\text { community-based food production initiatives }\end{array}$ & $\begin{array}{l}\text { Focused specifically on treatment or intervention } \\
\text { targeting a diagnosed illness, disease or condition }\end{array}$ \\
\hline Timeframe: & $\begin{array}{l}\text { Published between January 2014 and December } \\
2018\end{array}$ & $\begin{array}{l}\text { Published before January 2014 and after December } \\
2018\end{array}$ \\
\hline
\end{tabular}

loaded into the online bibliographic database, Rayyan (Qatar Computing Research Institute, Data Analytics, Doha, Qatar). Results were screened independently based on title and abstract by 14 assessors - seven pairs, ensuring 100\%of documents were double screened against the inclusion and exclusion criteria outlined in Table 1. Conflicts were resolved by discussion with a third-party reviewer. If a document did not explicitly indicate the inclusion criteria, an inclusive approach was taken, and it was considered for fulltext screening. Full-text screening was double screened by 14 assessors using RedCap software (Research Electronic Data Capture), which also facilitated the data abstraction.

\section{DATA CHARTING AND SYNTHESIS}

Full-text screening was conducted alongside data abstraction. Each document was examined stepwise as follows: (i) Is the publication primary research?; (ii) Does the publication concern some aspect of food production within the geographical area of interest?; (iii) Is the food production owned or managed locally?; (iv) Is the food predominantly produced for local consumption?; (v) Does the publication describe health, social, economic or environmental impacts of CFPIs?

Only those documents that were affirmative ("yes") for all five screening questions above, were included in the review. The data abstraction form (Online Supplementary Document, Appendix D) for eligible articles included details on the impacts assessed, study methods used, and whether a theoretical framework on the proposed relationships between the initiative and outcomes was presented.

In line with the scoping review methodology, study quality was not assessed nor were meta-analyses performed. ${ }^{13}$ In addition to the descriptive narrative, the results were summarised and presented in tables.

\section{RESULTS}

A total of 4842 articles were identified from eight databases. After removing duplicates, 4595 articles were screened at title and abstract level. Of these, 3790 articles (82.5\%) did not meet the inclusion criteria. There was disagreement between reviewers for 687 articles (14.9\%), and after discussion with a third reviewer, 142 of these were included. Thus, 260 articles were eligible for full text screening. Of these, 118 records were included in the review (Figure 1). ${ }^{14-131}$
Of the 118 studies included for full-text review, over half of the research was conducted in Kenya ( $n=63$ studies; $53.4 \%$ ), followed by South Africa ( $n=45$ studies; $38.1 \%$ ) and Cameroon ( $\mathrm{n}=10$ studies; 8.5\%). The research applied a range of quantitative ( $\mathrm{n}=63$ studies; $53.4 \%$ ), qualitative ( $\mathrm{n}=19$ studies; $16.1 \%$ ) and mixed method ( $\mathrm{n}=36$ studies; 30.5\%) approaches to evaluate the impacts of CFPIs. A majority of the studies had a cross-sectional design ( $\mathrm{n}=70$ studies; 59\%). Structured interviews, focus group discussion, and interviewer and self-completion questionnaires were the most common methods of data collection in assessing the impacts of CFPIs.

Aspects of study design and data collection methods are described as appropriate in the detailed sections on the types of impacts that were assessed.

\section{TYPES OF CFPIS BY COUNTRY}

Five major types of CFPIs were identified in collating the results: farming, fisheries, gardens, urban agriculture and agroforestry. Farming was further categorized by crop, livestock and unspecified (Table 2).

The most commonly evaluated CFPI was crop farming (n $=59$ studies; $50.0 \%$ ) and included a range of impacts across all three countries. Crop farming mainly consisted of smallholders and focused on a variety of crops, with maize most commonly specified. ${ }^{19,21,26,29,32,39,54,57,64,131}$ Livestock farming was only identified in Kenya and South Africa, with seven studies $(25.9 \%$ of the 27 studies reporting livestock farming) focused on dairy farming. ${ }^{16,28,37,39,51,61,78}$

Studies identifying gardens as a CFPI were predominantly from South Africa (87.5\%), as were studies focusing on urban agriculture (80\%). In contrast, studies focused on fisheries were predominantly conducted in Kenya (66.7\%). Agroforestry was the least reported CFPI, with only two studies identified in Kenya.

\section{IMPACTS OF CFPIS BY COUNTRY}

In collating the results, health, economic, environmental and social impacts of CFPIs were observed. Most studies examining impacts of CFPIs focused on the economic impact $(\mathrm{n}=80,67.8 \%$ ), followed by environmental impacts $(n=48,40.7 \%)$ and health impacts $(n=47,39.8 \%$,). Social impacts ( $\mathrm{n}=27,22.9 \%$,) were least examined. One study, from Kenya, examined all four impacts, 15 studies (12.7\%) eval- 


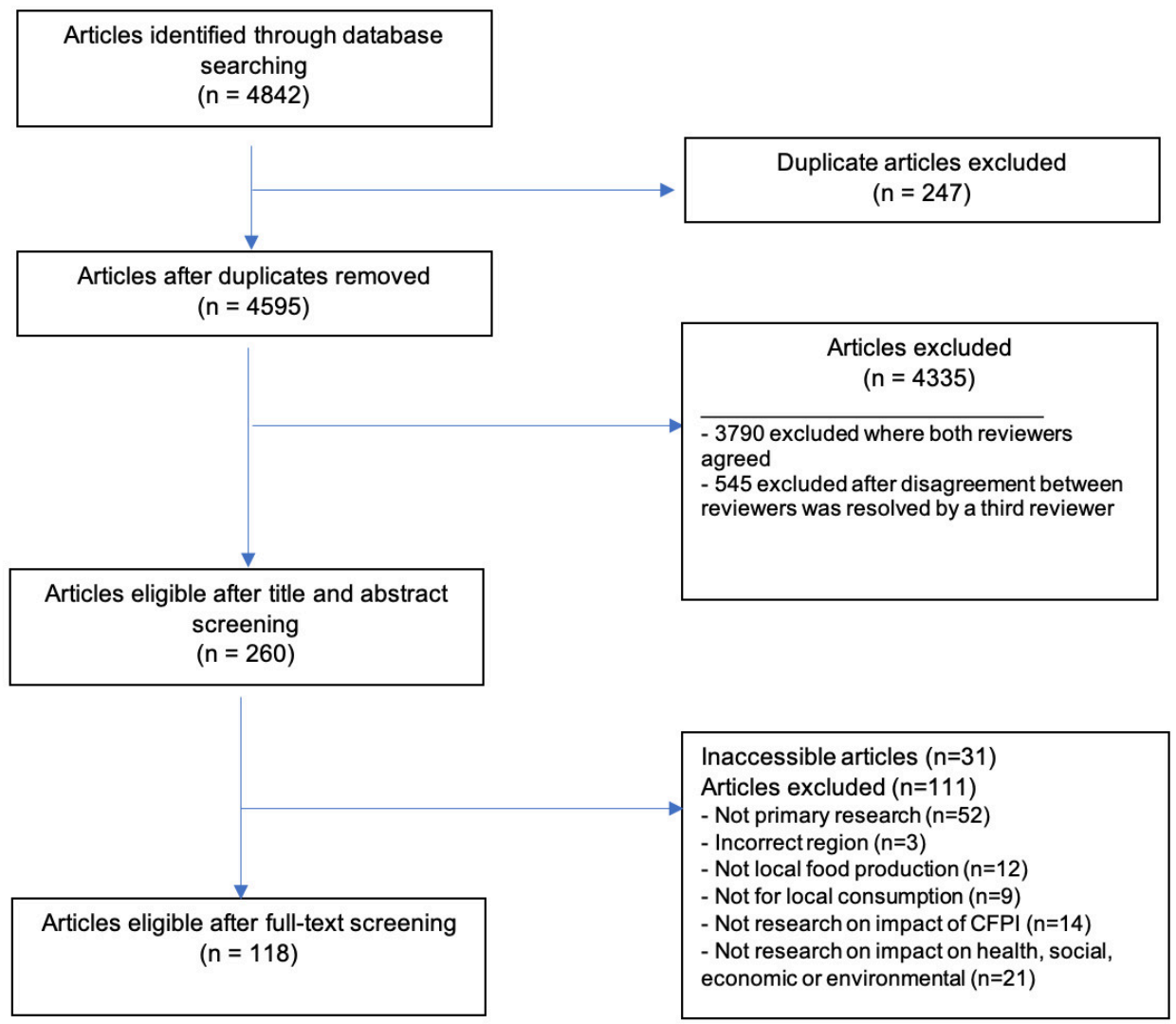

Figure 1. Flowchart of the literature search and screening

\begin{tabular}{|c|c|c|c|c|c|c|c|}
\hline \multirow[b]{2}{*}{$\begin{array}{l}\text { Country } \\
\text { (number of } \\
\text { studies) }\end{array}$} & \multicolumn{7}{|c|}{ Types of CFPI } \\
\hline & $\begin{array}{l}\text { Urban } \\
\text { Agriculture }\end{array}$ & $\begin{array}{l}\text { Farming- } \\
\text { Crop }\end{array}$ & $\begin{array}{l}\text { Farming- } \\
\text { Livestock }\end{array}$ & $\begin{array}{l}\text { Farming- } \\
\text { Unspecified }\end{array}$ & Fisheries & Agroforestry & Gardens \\
\hline Cameroon (10) & 0 & 6 & 0 & 3 & 1 & 0 & 0 \\
\hline Kenya (68) & 1 & 32 & 18 & 6 & 8 & 2 & 1 \\
\hline S. Africa (50) & 4 & 21 & 9 & 6 & 3 & 0 & 7 \\
\hline Total (128) & 5 & 59 & 27 & 15 & 12 & 2 & 8 \\
\hline
\end{tabular}

\section{Table 2. Matrix showing the number and type of CFPIs by country}

NB: the figures denote the number of studies in each category, with some studies including more than one type of CFPI. The shade of colour represents the quantiles based on total distribution of studies shown in table. The darker the colour, the higher the number of studies.

uated three impacts, 30 studies (25.4\%) assessed two impacts, and 72 studies (61.0\%) only examined one impact. The studies that evaluated multiple impacts most commonly looked at economic and health $(n=21)$, economic and social $(n=20)$ and economic and environmental $(n=19)$.

\section{KENYA}

The 68 studies conducted in Kenya assessed a total of 123 different impacts across the four impact categories. About $44 \%$ of the studies $(n=30)$ evaluated the health impacts of CFPIs which were mainly concentrated around crop and livestock farming. About $73 \%$ of the studies $(n=46)$ evaluated economic impacts with over half of those impacts com- ing from crop farming CFPIs. Of these studies, 28 (41.2\%) focused on only one impact category, whereas the others focused on a multitude of impacts - primarily economic and health $(n=17)$, and economic and environmental $(n=16)$.

\section{CAMEROON}

In Cameroon, 10 studies looked at 16 health, social, economic and environmental impacts (Figure 2). All of the CFPIs explored in these studies were centred around farming - with one study in the fisheries category looking exclusively at fishponds owned by household farms (109). Health impacts were least evaluated, $(n=2,20.0 \%)$, while economic impacts were most prominent, with seven of 10 studies 


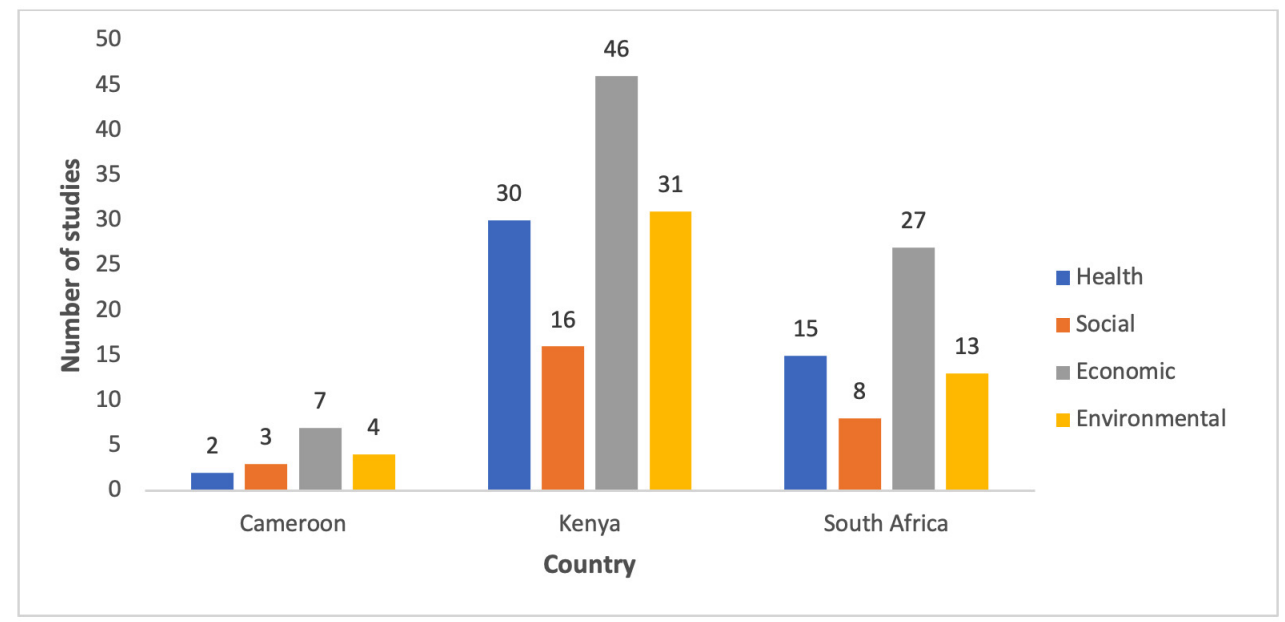

Figure 2. Number of impact categories by country

(70.0\%) discussing economic impacts of CFPIs. A majority of these studies were looked at in isolation of the other impacts, with seven out of 10 studies only assessing one impact.

\section{SOUTH AFRICA}

The 45 studies from South Africa looked at 63 health, social, economic and environmental impacts (Figure 2). As with studies in both Kenya and Cameroon, the majority of impacts were found in crop farming. Economic impacts were the most commonly assessed $(n=27 ; 42.9 \%)$. There were 15 health impacts evaluated (23.8\%), mainly in gardens ${ }^{75,77,116-118}$ and crop farming initiatives. ${ }^{15,79,105,125,126}$

\section{DETAILED DESCRIPTION OF TYPES OF IMPACTS}

The four broad impact categories - health, social, economic, environmental - were further divided into sub-categories based on the specific impacts that were assessed.

The distribution of impacts evaluated across 118 included studies show that the most reported impact sub-category overall was under economic impacts. This was the sub-category of household income \& wealth and it was reported by 15 studies in Kenya, 9 in South Africa and 3 in Cameroon, which accounts for $22.8 \%$ of studies $(n=27)$ overall.

Economic welfare \& security was reported as an impact in 26 studies (22.0\%), followed closely by production/catch/ yield (Economic) and agrobiodiversity (Environmental) both discussed within 23 studies each (19.5\%).

\section{HEALTH}

The types of health impacts that were assessed covered seven sub-categories. In order of frequency, they were food security, nutrition status, dietary intake, malnutrition, communicable diseases, indirect benefits and NCDs (Table 3). Food security was the leading health impact of CFPIs assessed, with 17 studies evaluating it (38.4\% of the 44 studies reporting on health impacts). These studies most commonly looked at food security as a standalone health impact, where the premise of the study was to assess food security within the household as a result of a particular programme $46,95,117$ or as a case study or evaluation of current community food production practices. ${ }^{15,20,45,66,73,120}$ When food security was evaluated in conjunction with other health impacts, they were almost exclusively nutrition status, dietary intake or malnutrition. ${ }^{17,20,47,70,77,116,126}$

Both nutrition status $(34.1 \% ; \mathrm{n}=15)$ and dietary intake $(31.8 \% ; n=14)$ were also prominent health impacts evaluated.

\section{SOCIAL}

Social impacts covered five categories: i) gender empowerment, ii) knowledge transfer and capacity building, iii) social capital, iv) education, and v) job opportunities (Table 4). Of these, gender empowerment, knowledge transfer and social capital were the most often studied. Of the 24 studies that evaluated social impacts of CFPIs, 31 social impacts were assessed.

Gender empowerment, knowledge transfer and capacity building, and social capital were evaluated in nine studies (37.5\%) each, often overlapping. The nine studies discussing gender empowerment assessed the influence and impact of CFPIs on empowering women. Social capital was the social impact most often evaluated alone, with six studies $(66.7 \%$ of the nine studies reporting on social capital) reporting it exclusively.

Job opportunities and education were only explored in studies from Kenya, with education linked to food security and nutrition status 66,90 and a positive impact on job opportunities within a community because of a CFPI. ${ }^{46,50}$ Gender empowerment in Kenya was the most reported social impact sub-category overall, evaluated by six studies (5.1\%). Knowledge transfer \& capacity building was the most prominent impact sub-category in South Africa $(n=4$ studies), while social capital was most studied in Cameroon ( $\mathrm{n}=2$ studies). 


\section{Types of Health Impacts}

\begin{tabular}{llllllll}
$\begin{array}{l}\text { Country (no. } \\
\text { studies) }\end{array}$ & $\begin{array}{l}\text { Nutrition } \\
\text { status }\end{array}$ & $\begin{array}{l}\text { Dietary } \\
\text { intake }\end{array}$ & NCDs & $\begin{array}{l}\text { Communicable } \\
\text { Disease }\end{array}$ & Malnutrition & $\begin{array}{l}\text { Food } \\
\text { security }\end{array}$ & $\begin{array}{l}\text { Indirect } \\
\text { benefits }\end{array}$ \\
\hline Cameroon (2) & 1 & 0 & 0 & 0 & 0 & 1 & 0 \\
Kenya (39) & 10 & 9 & 0 & 3 & 5 & 10 & 2 \\
S. Africa (21) & 4 & 5 & 1 & 2 & 2 & 6 & 1 \\
Total (62) & $\mathbf{1 5}$ & $\mathbf{1 4}$ & $\mathbf{1}$ & $\mathbf{5}$ & $\mathbf{7}$ & $\mathbf{1 7}$ & $\mathbf{3}$ \\
\hline
\end{tabular}

Table 3. Matrix showing number and types of health impacts of CFPIs investigated by country

NB: the figures indicate the number of studies in each category, with some studies including more than one category. The shade of colour represents the quantiles based on total distribution of types of impacts. The darker the colour, the higher the number of studies.

\begin{tabular}{|c|c|c|c|c|c|}
\hline \multirow[b]{2}{*}{$\begin{array}{l}\text { Country (no. } \\
\text { studies) }\end{array}$} & \multicolumn{5}{|c|}{ Types of Social Impacts } \\
\hline & $\begin{array}{l}\text { Gender } \\
\text { empowerment }\end{array}$ & $\begin{array}{l}\text { Knowledge transfer \& } \\
\text { capacity building }\end{array}$ & Education & Job opportunities & Social capital \\
\hline Cameroon (3) & 1 & 0 & 0 & 0 & 2 \\
\hline Kenya (19) & 6 & 5 & 2 & 2 & 4 \\
\hline S. Africa (9) & 2 & 4 & 0 & 0 & 3 \\
\hline Total (31) & 9 & 9 & 2 & 2 & 9 \\
\hline
\end{tabular}

Table 4. Matrix showing types of social impacts of CFPIs investigated by country

NB: the figures indicate the number of studies in each category, with some studies including more than one category. The shade of colour represents the quantiles based on total distribution of types of impacts. The darker the colour, the higher the number of studies.

\begin{tabular}{lllllll}
\hline \multirow{2}{*}{$\begin{array}{l}\text { Country (no. } \\
\text { studies) }\end{array}$} & $\begin{array}{l}\text { Types of Economic Impacts } \\
\text { income \& wealth }\end{array}$ & $\begin{array}{l}\text { Economic Welfare } \\
\text { \& security }\end{array}$ & $\begin{array}{l}\text { Production/ } \\
\text { Catch/ Yield }\end{array}$ & $\begin{array}{l}\text { Technical } \\
\text { efficiency }\end{array}$ & Cost & $\begin{array}{l}\text { Profitability } \\
\text { \& Revenue }\end{array}$ \\
\hline Cameroon (8) & $\mathbf{3}$ & $\mathbf{2}$ & 2 & 1 & 0 & 0 \\
Kenya (54) & 15 & 11 & 16 & 1 & 3 & 8 \\
S. Africa (35) & $\mathbf{9}$ & 13 & 5 & 1 & 1 & 6 \\
Total (97) & $\mathbf{2 7}$ & $\mathbf{2 6}$ & $\mathbf{2 3}$ & $\mathbf{3}$ & $\mathbf{4}$ & $\mathbf{1 4}$ \\
\hline
\end{tabular}

Table 5. Matrix showing types of economic impacts of CFPIs investigated by country

NB: the figures indicate the number of studies in each category, with some studies including more than one category. The shade of colour represents the quantiles based on total distribution of types of impacts. The darker the colour, the higher the number of studies.

\section{ECONOMIC}

Economic impacts covered six categories. In order of frequency, they were household income and wealth, economic welfare and security, production/catch/yield, profitability and revenue, cost, and technical efficiency. Of the 73 studies that evaluated economic impacts of CFPIs, 97 economic impacts were assessed (Table 5 ).

Twenty-seven of these studies (37.0\%) evaluated household income and wealth, though economic welfare and security $(n=26 ; 35.6 \%)$ and production/catch/yield $(n=23$; $31.5 \%$ ) were the most prominent impacts assessed. Economic welfare and security often overlapped with both household income and wealth ( $\mathrm{n}=7$ studies) $34,53,54,62,89,113,123$ and with production/catch/yield (n $=6$ studies), ${ }^{15,48,81,101,123,131}$ showing the diverse nature of economic welfare and security, and the possible link to other economic impacts of CFPIs.

\section{ENVIRONMENTAL}

Environmental impacts covered four categories. In order of frequency, they were agrobiodiversity, water availability, soil quality and greenhouse gases, and air pollution. Of the 40 studies that evaluated environmental impacts of CFPIs, 48 environmental impacts were assessed (Table 6). 


\begin{tabular}{lllll}
\hline & \multicolumn{2}{l}{ Types of Environmental Impacts } & Water availability & $\begin{array}{l}\text { Greenhouse gases \& } \\
\text { pollution }\end{array}$ \\
\cline { 2 - 5 } $\begin{array}{l}\text { Country (no. } \\
\text { studies) }\end{array}$ & Agrobiodiversity & Soil Quality & 2 & 1 \\
\hline Cameroon (6) & 3 & 0 & 8 & 4 \\
Kenya (31) & 15 & 4 & 1 & 1 \\
S. Africa (11) & 5 & 4 & $\mathbf{1 1}$ & $\mathbf{6}$ \\
Total (48) & $\mathbf{2 3}$ & $\mathbf{8}$ & & \\
\hline
\end{tabular}

\section{Table 6. Matrix showing types of environmental impacts of CFPIs investigated by country}

NB: the figures indicate the number of studies in each category, with some studies including more than one category. The shade of colour represents the quantiles based on total distribution of types of impacts. The darker the colour, the higher the number of studies.

The most prominent environmental impact was agrobiodiversity, with 23 studies (57.5\%) evaluating this impact, while the impact that was least assessed was greenhouse gases and air pollution, with six studies (15\%). Agrobiodiversity often encompassed conservation initiatives and diversifying species or crops, which were intended to improve agrobiodiversity. CFPIs assessing agrobiodiversity were often programmes and initiatives working with communities to think and act longer term and more sustainably, such as interventions at a household level to support sustainable self-provisioning of crops, livestock or fishing as a source of affordable nutrients. ${ }^{44,49,121}$ Studies reporting assessments of practices already in place as opposed to new initiatives demonstrated the negative impact on agrobiodiversity, such as loss of crops and livestock, ${ }^{45}$ changes in fish populations because of overfishing 65 and changes of land use or cover. ${ }^{86,88}$

South Africa had the highest proportion of studies that evaluated urban agriculture initiatives ( $\mathrm{n}=4$ of $5(80 \%)$ ). These studies aimed to demonstrate that urban agriculture is a good model for socioeconomically marginalised populations with the potential to reduce negative environmental impacts. ${ }^{14,40,44,118}$

Studies assessing the impact of CFPIs on water availability $(\mathrm{n}=11 ; 27.5 \%)$ evaluated both water accessibility and quality, such as pressure exerted on water resources and land by farmers ${ }^{85}$ or the increased water pollution. ${ }^{94}$ Soil quality was discussed in the context of soil fertility from use of land ${ }^{21,40}$ and all eight studies assessing soil quality were crop or livestock farming CFPIs.

\section{THEORETICAL FRAMEWORKS}

None of the studies reviewed made explicit use of a theoretical framework on the relationships between the CFPIs and the impacts being studied to guide their hypotheses and analyses. Similarly, not one study derived a theoretical framework, or interpreted their findings within the context of an existing theoretical framework, on how CFPIs impact health, economic, social and environmental well-being.

\section{DISCUSSION}

Our aim was to provide a systematic and comprehensive overview of research evidence on the health, social, economic and environmental impacts of CFPIs in Cameroon,
Kenya and South Africa published over a recent 5-year period (2014 to 2018). This was undertaken to complement and to help inform a programme of work into the upstream determinants of diet and related non-communicable diseases in these three countries. ${ }^{12}$ We found a large amount of published research studies, with there being significantly more studies and therefore CFPIs and impacts measured, in Kenya and South Africa than in Cameroon. The volume of publications suggests a significant interest in community initiatives and a recognition of the potential importance of CFPIs for health, social, economic and environmental wellbeing in Cameroon, Kenya and South Africa.

However, there was a relative lack of studies in certain areas and the majority of studies were cross sectional in design, unable therefore to properly investigate causal relationships. Findings indicate a predominance of research focusing on the environmental impact of CFPIs, and very limited evidence of CFPI impact on health and social wellbeing, particularly NCDs, education and job opportunities. The lack of evidence on relationships to the risk of NCDs across all countries - with only 1 of the 118 studies evaluating NCDs - is significant given the increasing burden of these conditions in Sub-Saharan Africa. 2,6 This also highlights the need for larger prospective studies that look not only into determinants but also disease and health end points and emphasises that it is critical that future research also focuses on health and social implications of CFPIs if we want to make sure that NCDs-related SDG targets are met for these countries.

The evidence collated in this review supports the argument that community food production programmes and initiatives benefit health, economic and social wellbeing and support sustainability within the environment. Food security problems are often dealt with in silos, with relevant sectors and institutions often not collaborating to ensure their policies consistently support food security. ${ }^{1}$ The fact that only 46 studies (38.9\%) in this review covered more than one type of impact suggests that there is room for more inter or transdisciplinary research to inform policy aimed at improving food security and nutrition. It is noteworthy that none of the identified studies explicitly used or proposed a theoretical framework on the relationships between CFPIs and impacts to guide their study design or the interpretation and presentation of their findings.

The FAO Africa Regional Overview of Food Security and Nutrition indicates that coordinated food system wide pol- 
icy initiatives, including in local food production, handling, storage and processing, food trade and marketing, consumer demand, food preparation and preferences should be explored as policy tools, in order to identify the most effective ways to support healthy diets and wellbeing at a national level. The disproportionate effect that COVID-19 is having across countries in Africa on food insecurity has amplified the importance of understanding the evidence that exists on the role of CFPIs in tackling food insecurity and malnutrition and where new research is required.

As research in this area further evolves, there is also the potential to construct coherent and comprehensive methodological approaches for monitoring and evaluating CFPIs and their associated impacts, underpinned by bespoke and well-founded causal frameworks that are tested and refined iteratively as evidence grows.

This systematic scoping review has identified a number of areas for potential further exploration, including full systematic reviews focussed on specific areas, such as how CFPIs relate to dietary quality and other outcomes in local populations.

\section{STRENGTHS AND LIMITATIONS}

The main strength of our review is the extensive coverage of the state of research. The broad range of disciplines covered as well as the extensive and comprehensive search strategy that was undertaken across health, social sciences, economics, agriculture and regional databases greatly reduced the risk of bias of skewing screening towards a particular discipline. The databases were identified with input from a multidisciplinary team, with a diverse range of backgrounds including public health nutrition, social science, health economics and agriculture. Further strengths of our review include the approach taken for literature screening and data abstraction, where two assessors reviewed each article. This increased the likelihood of literature that met the inclusion criteria being included in the final review.

We acknowledge that we used the term 'impact' as a 'catch all' that includes potential impacts, outcomes and associations. As is the case with a systematic scoping review, we did not attempt to evaluate the risk of bias or quality of the studies. Rather we aimed to provide an overview of the literature and the potential impacts as reported by the authors. Two further limitations are that firstly we only included research from 3 countries, chosen as they are part of a larger programme. ${ }^{12}$ A second limitation is that our findings essentially provide a recent 'snapshot' of published research studies in this area, being limited to a 5-year period and to published, but not grey, literature.

\section{CONCLUSION}

In this systematic scoping review, we have summarised published research from a broad range of disciplines into the impacts of CFPIs in three African countries. The evidence we found was largely limited to descriptive studies focussing on a single outcome or impact measure. These studies have been undertaken within the context of the urgent need for coordinated food system wide interventions to address the very high and growing levels of food insecurity and all types of malnutrition. This need has become even more acute and urgent with the disruptions to food systems caused by the COVID-19 pandemic.

While we cannot claim the countries reported on are representative of other parts of Africa, we believe that what we present provides an interesting and useful snapshot that can help to guide further work. We found a large number of studies across a broad range of impacts, which suggests that more focussed, in-depth, evidence appraisals in the form of full systematic reviews would be worthwhile. However, we also found that the vast majority of studies were cross sectional, thus unable to investigate longitudinal relationships, and that they typically had a narrow, often single, disciplinary focus. In addition, none of the studies we identified made use of an explicit theoretical framework on the links between CFPIs and the outcomes of interest.

The need for transdisciplinary research is emphasized in a 2015 IPES Food report, within which the authors make the case for a 'new transdisciplinary science of sustainable food systems. ${ }^{132}$ Our scoping review, while only representing a 'snapshot' in three countries, suggests that such research in these countries is at best infrequent. Ideally, the design of such research should be guided by the use of explicit theoretical frameworks that hypothesize the relationships between CFPIs and their impacts. ${ }^{132,133}$

\section{FUNDING}

The authors ABP, KO, PW, and NU were funded by the National Institute for Health Research (NIHR) (GHR: 16/137/ 34) using UK aid from the UK Government to support global health research. The views expressed in this publication are those of the author(s) and not necessarily those of the NIHR or the UK Department of Health and Social Care.

\section{AUTHORSHIP CONTRIBUTIONS}

GH developed the study design, scoping review protocol, data collection and collation, as well as writing, editing, and approving the manuscript.

$\mathrm{ABP}, \mathrm{DB}$ contributed to the pilot study, scoping review protocol, data collection and collation, as well as editing and approving the manuscript.

CMM, JMB, HS, KO, MM, PW, LT, EM, LG contributed to data collection and document screening, editing and approving the manuscript

NU oversaw the review for the duration of the project as senior author; contributed to developing the study design; contributed to the pilot study; acted as third-party reviewer during screening process; wrote parts of the manuscript; and was involved in the editing and approval process.

All authors approved the final manuscript as submitted

\section{COMPETING INTERESTS}

The authors completed the Unified Competing Interest form at www.icmje.org/coi_disclosure.pdf (available upon request from the corresponding author), and declare no conflicts of interest. 


\section{CORRESPONDENCE TO:}

\section{Gráinne Hutton, MPhil}

Forvie Site, Robinson Way,

Cambridge CB2 0SR, United Kingdom

gbhutton@gmail.com
Submitted: November 18, 2020 GMT, Accepted: February 08, 2021 GMT 


\section{REFERENCES}

1. The State of Food Security and Nutrition in the World (SOFI): Safeguarding against economic slowdowns and downturns | World Food Programme. Wfp.org. Published online 2019. Accessed July 22, 2019. https://www.wfp.org/publications/2019-state-f ood-security-and-nutrition-world-sofi-safeguardingagainst-economic

2. Willett W, Rockström J, Loken B, Springmann M, Lang T, Vermeulen S, et al. The Lancet Commissions Food in the Anthropocene: The EAT-Lancet Commission on healthy diets from sustainable food systems Executive summary. www.thelancet.com. 2019;393:447. Accessed July 22, 2019. http://dx.doi.or g/10.1016/

3. GBD 2017 Diet Collaborators. Health effects of dietary risks in 195 countries, 1990-2017: A systematic analysis for the Global Burden of Disease Study 2017. Lancet (London, England).

2017;393(10184):1958-1972. Accessed July 22, 2019. h ttp://www.ncbi.nlm.nih.gov/pubmed/30954305

4. Kearney J. Food consumption trends and drivers. Phil Trans R Soc B. 2010;365(1554):2793-2807. doi:1 0.1098/rstb.2010.0149

5. Winichagoon P, Margetts BM. The double burden of malnutrition in low- and middle- income countries. Published online 2017. Accessed July 22, 2019. http s://api.semanticscholar.org/CorpusID:43962433

6. Steyn NP, Mchiza ZJ. Obesity and the nutrition transition in Sub - Saharan Africa. Ann NY Acad Sci. 2014;1311(1):88-101. doi:10.1111/nyas.12433

\section{Global Nutrition Report: Action on Equity to End} Malnutrition. Development Initiatives; 2020. Accessed October 3, 2020. https://globalnutritionreport.org/res ources/nutrition-profiles/africa/\#profile

8. FAO, ECA, AUC. Africa Regional Overview of Food Security and Nutrition 2019. Accra; 2020. Accessed October 3, 2020. https://doi.org/10.4060/ca7343en

9. Global Report on Food Crises. Food Security Information Network; 2020. Accessed October 3, 2020. http://ebrary.ifpri.org/utils/getfile/collection/p1 5738coll2/id/133693/filename/133904.pdf

10. Haynes E, Brown CR, Wou C, Vogliano C, Guell C, Unwin N. Health and other impacts of community food production in Small Island Developing States: A systematic scoping review. Rev Panam Salud Publica. 2018;42:1-9. doi:10.26633/rpsp.2018.176
11. Monteiro CA, Cannon G, Levy RB, et al. NOVA. The star shines bright. World Nutrition. 7(1-3):28-38. https://archive.wphna.org/wp-content/uploads/2016/ 01/WN-2016-7-1-3-28-38-Monteiro-Cannon-Levy-e t-al-NOVA.pdf

12. Oni T, Assah F, Erzse A, et al. The global diet and activity research (GDAR) network: A global public health partnership to address upstream NCD risk factors in urban low and middle-income contexts. Global Health. 2020;16(1). doi:10.1186/s12992-020-00 630-y

13. Tricco AC, Lillie E, Zarin W, et al. PRISMA Extension for Scoping Reviews (PRISMA-ScR): Checklist and Explanation. Ann Intern Med. 2018;169(7):467. doi:10.7326/m18-0850

14. Olivier DW. A cropping system for resourceconstrained urban agriculture: Lessons from Cape Town. Sustainability. 2018;10(12):4804. doi:10.3390/s u10124804

15. Modi AT. A simple model to evaluate integrated vegetable production for food security in KwaZuluNatal, South Africa. Food Res Int. 2015;76(4, SI):946-952. doi:10.1016/j.foodres.2015.04.037

16. Anyango G, Mutua F, Kagera I, Andang P, Grace D, Lindahl JF. A survey of aflatoxin M1 contamination in raw milk produced in urban and peri-urban areas of Kisumu County, Kenya. Infection Ecology \& Epidemiology. 2018;8(1):1547094. doi:10.1080/200086 $\underline{86.2018 .1547094}$

17. Dumas SE, Maranga A, Mbullo P, et al. "Men Are in Front at Eating Time, but Not When It Comes to Rearing the Chicken": Unpacking the Gendered Benefits and Costs of Livestock Ownership in Kenya. Food Nutr Bull. 2018;39(1):3-27. doi:10.1177/0379572 117737428

18. Bodjongo MJM, Sikod F. Access to the Urban Markets and Variation of Rural Farmers income of the Informal Sector in Cameroon. Revue d'économie régionale et urbaine. 2017;(2):357-375. https://ideas.re pec.org/a/cai/rerarc/reru_172 0357.html

19. Mburu SW, Koskey G, Kimiti JM, Ombori O, Maingi JM, Njeru EM. Agrobiodiversity conservation enhances food security in subsistence-based farming systems of Eastern Kenya. Agric \& Food Secur. 2016;5(1). doi:10.1186/s40066-016-0068-2 
20. Hamann S. Agro-industrialisation and food security: Dietary diversity and food access of workers in Cameroon's palm oil sector. Globalizations. 2018;39(1):72-88. doi:10.1080/02255189.2017.133607 $\underline{9}$

21. Berazneva J, Lee DR, Place F, Jakubson G. Allocation and Valuation of Smallholder Maize Residues in Western Kenya. Ecol Econ. 2018;152:172-182. doi:10.1016/i.ecolecon.2018.05.02 $\underline{4}$

22. Nyongesa D, Mabele RB, Mutoni CK, Esilaba AO. An economic analysis of gender roles in soya bean value addition and marketing in Kenya: A case of smallholder farms in Western Kenya. Int J Agric Resour Gov Ecol. 2018;14(3):237-259. doi:10.1504/ijar ge.2018.10018634

23. Mungofa N, Malongane F, Tabit FT. An Exploration of The Consumption, Cultivation And Trading of Indigenous Leafy Vegetables in Rural Communities in the Greater Tubatse Local Municipality, Limpopo Province, South Africa. J Fam Ecol Consum Sci. 2018;3(3):53-67. https://www.researc hgate.net/publication/329643269_An_exploration_o f the consumption_cultivation_and trading of indige nous leafy vegetables in rural communities in the $g$ reater_Tubatse_Local_Municipality_Limpopo_Provinc e South Africa

24. Fèvre EM, de Glanville WA, Thomas LF, Cook EAJ, Kariuki S, Wamae CN. An integrated study of human and animal infectious disease in the Lake Victoria crescent small-holder crop-livestock production system, Kenya. BMC Infect Dis. 2017;17(1). doi:10.118 6/s12879-017-2559-6

25. Senyolo GM, Wale E, Ortmann GF, Toerien DF. Analysing the value chain for African leafy vegetables in Limpopo Province, South Africa. COGENT Soc Sci. 2018;4(1):1509417. doi:10.1080/23311886.2018.15094 $\underline{17}$

26. Iortyom ET, Mazinyo SP, Nel W. Analysis of the economic impact of Rural Enterprise Development Hub Project on maize farmers in Mqanduli, South Africa. Indian J Agric Res. 2018;52(3):243-249. doi:1 $\underline{0.18805 / \text { ijare.a-319 }}$

27. Iannotti L, Lesorogol C. Animal milk sustains micronutrient nutrition and child anthropometry among pastoralists in Samburu, Kenya. Am J Phys Anthropol. 2014;155(1):66-76. doi:10.1002/ajpa.22547

28. Ondieki GK, Ombui JN, Obonyo M, Gura Z, Githuku J, Orinde AB, et al. Antimicrobial residues and compositional quality of informally marketed raw cow milk, Lamu West Sub-County, Kenya, 2015. Pan Afr Med J. 2017;28(Suppl 1):5. doi:10.11604/pamj.sup p.2017.28.1.9279
29. Nkuekam GK, Cowan DA, Valverde A. Arable agriculture changes soil microbial communities in the South African Grassland Biome. S Afr J Sci. 2018;114(5-6). doi:10.17159/sajs.2018/20170288

30. Addo-Bediako A, Marr SM, Jooste A, Luus-Powell WJ. Are metals in the muscle tissue of Mozambique tilapia a threat to human health? A case study of two impoundments in the Olifants River, Limpopo province, South Africa. Ann Limnol J Limnol. 2014;50(3):201-210. doi:10.1051/limn/2014015

31. Coetzee HC, Nell W, van Eeden ES, De Crom EP. Artsanal fisheries in the Ndumo area of the lower phongolo river floodplain, South Africa. Koedoe. 2015;57(1):1-6. doi:10.4102/koedoe.v57i1.1248

32. Bahta YT, Owusu-Sekyere E, Tlalang BE. Assessing participation in homestead food garden programmes, land ownership and their impact on productivity and net returns of smallholder maize producers in South Africa. Agrekon. 2018;57(1):49-63. doi:10.1080/03031853.2018.1437051

33. Darling ES. Assessing the effect of marine reserves on household food security in Kenyan coral reef fishing communities. Clifton J, ed. PLOS ONE. 2014;9(11):e113614. doi:10.1371/journal.pone.01136 $\underline{14}$

34. Thom A, Jonas N. Assessing the impacts of a donor-funded agricultural extension service on smallholders in Umzimkhulu, South Africa. Acta Hortic. 2016;(1128):305-314. doi:10.17660/actahorti c. 2016.1128 .46

35. Molefi SH, Mbajiorgu CA. Assessing the potential of beef cattle farming as contributor to income of communal households of Chief Albert Luthuli municipality in Mpumalanga province, South Africa. INDIAN J Anim Res. 2017;51(2):350-357. doi:10.1880 $\underline{5 / \text { ijar.9552 }}$

36. Muzangwa L, Mnkeni PNS, Chiduza C. Assessment of Conservation Agriculture Practices by Smallholder Farmers in the Eastern Cape Province of South Africa. Agronomy. 2017;7(3):46. doi:10.3390/agronomy70300 $\underline{46}$

37. Agutu FO, Ondiek JO, Bebe BO. Associations between intensification interventions and negative externalities in smallholder dairy farms in the kenyan highlands. Livest Res Rural Dev. 2018;30(4). http://ww w.lrrd.org//rrd30/4/agutu30061.html

38. Richards S, VanLeeuwen J, Shepelo G, Gitau GK, Kamunde C, Uehlinger F, et al. Associations of farm management practices with annual milk sales on smallholder dairy farms in Kenya. Vet world. 2015;8(1):88-96. https://doi.org/ 
39. Ojiem JO, Franke AC, Vanlauwe B, de Ridder N, Giller KE. Benefits of legume-maize rotations: Assessing the impact of diversity on the productivity of smallholders in Western Kenya. F Crop Res. 2014;168:75-85. doi:10.1016/j.fcr.2014.08.004

40. Olivier DW, Heinecken L. Beyond Food Security: Women's Experiences of Urban Agriculture in Cape Town. Agric Human Values. 2017;34(3):743-755. doi:1 $\underline{0.1007 / \mathrm{s} 10460-017-9773-0}$

41. Cosyns H, Van Damme P, De Wulf R, Degrande A. Can Rural Development Projects Generate Social Capital? A Case Study of Ricinodendron heudelotii Kernel Marketing in Cameroon. Small-Scale For. 2014;13(2):163-182. doi:10.1007/s11842-013-9247-1

42. Githunguri CM, Lung'ahi EG, Kabugu J, Musili R. Cassava Farming Transforming Livelihoods Among Smallholder Farmers in Mutomo a Semi-arid District in Kenya. In: Filho WL, Esilaba AO, Rao KPC, Sridhar $\mathrm{G}$, eds. Adapting African Agriculture To Climate Change: Transforming Rural Livelihoods. Climate Change Management; 2015:225-233.

43. Sinyolo S, Mudhara M. Collective action and rural poverty reduction: Empirical evidence from kwazulunatal, South Africa. Agrekon. 2018;57(1):78-90. doi:1 $\underline{0.1080 / 03031853.2018 .1451349}$

44. Oldewage-Theron WH, Duvenage SS, Egal AA, Lyford C. Comparative analysis of the factors contributing to sustainability of a food and nutrition intervention programme: Two case studies from South Africa. Eval Program Plann. 2018;71:51-57. do i:10.1016/j.evalprogplan.2018.08.003

45. Lotesiro JE, King'ori AM, Bebe BO. Comparative assessment of livelihood roles of indigenous chicken in pastoral and agricultural households of Kenya. Livest Res Rural Dev. 2017;29(12). http://41.89.96.81:8 080/xmlui/handle/123456789/1312

46. King EG, Unks RR, German L. Constraints and capacities for novel livelihood adaptation: Lessons from agricultural adoption in an African dryland pastoralist system. Reg Environ Change. 2017;18(5):1403-1410. doi:10.1007/s10113-017-127 $\underline{0-\mathrm{X}}$

47. Hotz C, Pelto G, Armar-Klemesu M, Ferguson EF, Chege P, Musinguzi E. Constraints and opportunities for implementing nutrition-specific, agricultural and market-based approaches to improve nutrient intake adequacy among infants and young children in two regions of rural Kenya. Matern Child Nutr. 2016;11(Suppl 3):39-54. doi:10.1111/mcn.12245
48. Ng'endo M, Bhagwat S, Keding. Contribution of Nutrient Diversity and Food Perceptions to Food and Nutrition Security Among Smallholder Farming Households in Western Kenya: A Case Study. Food Nutr Bull. 2017;39(1):86-106. https://doi.org/10.117 7\%2F0379572117723135

49. Becu N, Raimond C, Garine E, Deconchat M, Kokou K. Coupling Environmental and Social Processes to Simulate the Emergence of a Savannah Landscape Mosaic Under Shifting Cultivation and Assess its Sustainability. JASSS. 2014;17(1). doi:10.18 $\underline{564 / j a s s s .2397}$

50. Duncan AJ, Bachewe F, Mekonnen K, et al. Crop residue allocation to livestock feed, soil improvement and other uses along a productivity gradient in Eastern Africa. Agric Ecosyst Environ.

2016;228:101-110. doi:10.1016/j.agee.2016.05.011

51. Muraya J, Vanleeuwen JA, Gitau GK, Wichtel JJ, Makau DN, Crane MB, et al. Cross-sectional study of productive and reproductive traits of dairy cattle in smallholder farms in Meru, Kenya. Livestock Research for Rural Development. 2018;30(10). http://www.lrrd.o rg/lrrd30/10/imura30171.html

52. Benjamin EO, Ola O, Buchenrieder G. Does an agroforestry scheme with payment for ecosystem services (PES) economically empower women in subSaharan Africa? Ecosyst Serv. 2018;31(A):1-11. doi:1 $\underline{0.1016 / j . e c o s e r .2018 .03 .004}$

53. Mwambi MM, Oduol J, Mshenga P, Saidi M. Does contract farming improve smallholder income? The case of avocado farmers in Kenya. Journal of Agribusiness in Developing and Emerging Economies. 2016;6(1):2-20. doi:10.1108/jadee-05-2013-0019

54. Fischer K, Hajdu F. Does raising maize yields lead to poverty reduction? A case study of the Massive Food Production Programme in South Africa. Land use policy. 2015;46:304-313. doi:10.1016/j.landusepo $\underline{1.2015 .03 .015}$

55. Tamako N, Thamaga-Chitja JM. Does Social Capital Play A Role In Climate Change Adaptation Among Smallholder Farmers For Improving Food Security And Livelihoods? Journal of Consumer Sciences. 2017;(2):16-27. https://www.ajol.info/inde x.php/ifecs/article/view/156132

56. Cholo MS, Oluwatayo IB, Chaminuka P. Economic analysis of integrated game-livestock farming as an alternative land use option in Rural Limpopo province, South Africa. Agroecology and Sustainable Food Systems. 2017;42(4):407-431. doi:10.1080/21683 $\underline{565.2017 .1373382}$ 
57. Bett EK, Ayieko DM. Economic potential for conversion to organic farming: a net present value analysis in the East Mau Catchment, Nakuru, Kenya. Environ Dev Sustain. 2017;19(4):1307-1325. doi:10.10 $\underline{80 / 21683565.2017 .1373382}$

58. Ayuya OI, Gido EO, Bett HK, Lagat JK, Kahi AK, Bauer S. Effect of Certified Organic Production Systems on Poverty among Smallholder Farmers: Empirical Evidence from Kenya. Environ Dev Sustain. 2016;67:27-37. doi:10.1007/s10668-016-9800-0

59. Nguka G, Shitote Z, Wakhungu J, China S. Effect of fish farming on household food security in Western Kenya. AJFAND. 2017;17(1):11657-11672. doi:10.1869 7/ajfand.77.15965

60. Musazura W, Odindo AO, Bame IB, Tesfamariam EH. Effect of irrigation with anaerobic baffled reactor effluent on Swiss chard (Beta vulgaris cicla.) yield, nutrient uptake and leaching. Journal of Water Reuse and Desalination. 2015;5(4):592-609. doi:10.2166/wr d.2015.011

61. Colleen W, VanLeeuwen J, MacLellan D, Taylor J, Mbugua S. Effect of nutrition education and dairy group membership on nutrition knowledge, practices and diet quality for rural Kenyan farm women. AJFAND. 2017;17(3):12343-12361. doi:10.18697/ajfan d.79.15350

62. Nchanji YK, Nkongho RN, Mala WA, Levang P. Efficacy of oil palm intercropping by smallholders. Case study in South-West Cameroon. Agroforest Syst. 2016;90(3):509-519. doi:10.1007/s10457-015-9873-z

63. Ombogoh DB, Tanui J, McMullin S, Muriuki J, Mowo J. Enhancing adaptation to climate variability in the East African highlands: A case for fostering collective action among smallholder farmers in Kenya and Uganda. Clim Dev. 2016;10(1):61-72. doi:10.1080/ $\underline{17565529.2016 .1174665}$

64. Mucheru-Muna M, Mugendi D, Pypers P, et al. Enhancing Maize Productivity And Profitability Using Organic Inputs And Mineral Fertilizer In Central Kenya Small-Hold Farms. Ex Agric. 2014;50(2):250-269. doi:10.1017/s0014479713000525

65. Wang JY, Mo F, Nguluu SN, et al. Exploring microfield water-harvesting farming system in dryland wheat (Triticum aestivum L.): An innovative management for semiarid Kenya. F Crop Res. 2016;196:207-218. doi:10.1016/j.fcr.2016.07.001

66. Eidt CM, Hickey GM, Pelletier B. Exploring the relationships between gender, social networks, and agricultural innovation in two smallholder farming communities in Machakos County, Kenya. In: Food Security, Gender and Resilience: Improving Smallholder and Subsistence Farming. Taylor and Francis Inc.; 2016:44-54. https://doi.org/10.4324/9781315745855
67. Manyaja RS, Anim FDK, Gwata ET. Factors contributing to rural household consumption expenditure of farmers cultivating legumes in the Limpopo Province of South Africa. J Hum Ecol. 2018;62(1-3). doi:10.31901/24566608.2018/62.1-3.29 $\underline{65}$

68. Ortiz-Gonzalo D, Vaast P, Oelofse M, de Neergaard A, Albrecht A, Rosenstock TS. Farm-scale greenhouse gas balances, hotspots and uncertainties in smallholder crop-livestock systems in Central Kenya. Agric Ecosyst Environ. 2017;248:58-70. doi:10.1016/i.a gee.2017.06.002

69. Self J, Kedera E, Grant F, Wamalwa M, Hu J, Low J, et al. Financial costs of Mama-SASHA-a project to improve health and nutrition through an integrated orange flesh sweet potato production and health service delivery model. FASEB J. 2014;28(1). doi:10.10 96/fasebj.28.1_supplement.132.6

70. Fiorella KJ, Hickey MD, Salmen CR, et al. Fishing for food? Analyzing links between fishing livelihoods and food security around Lake Victoria, Kenya. Food Sec. 2014;6(6):851-860. doi:10.1007/s12571-014-039 $\underline{3-\mathrm{x}}$

71. Andersson CIM, Chege CGK, Rao EJO, Qaim M. Following up on small holder farmers and supermarkets in Kenya. American Journal of Agricultural Economics. 2015;97(4):1247-1266. doi:1 0.1093/ajae/aav006

72. Taruvinga B, Ndou P, Hlerema IN, Maraganedzha TL, Du Plooy CP, Venter S. Fostering linking social capital for successful agricultural development projects in South Africa. Agrekon. 2017;56(1):28-39. d oi:10.1080/03031853.2017.1283243

73. Oguge N, Oremo F. Fostering the use of rainwater for off-season small-scale irrigation in srid and semiarid areas of Kenya. In: Rainwater-Smart Agriculture in Arid and Semi-Arid Areas. Springer International Publishing; 2017:159-174. https://doi.org/10.1007/97 8-3-319-66239-8 9

74. Keding GB, Kehlenbeck K, Kennedy G, McMullin S. Fruit production and consumption: Practices, preferences and attitudes of women in rural western Kenya. Food Sec. 2017;9(3):453-469. doi:10.1007/s125 71-017-0677-z

75. Zimpita T, Biggs C, Faber M. Gardening practices in a rural village in South Africa 10 years after completion of a home garden project. Food Nutr Bull. 2015;36(1):33-42. doi:10.1177/156482651503600104

76. de Jager I, Abizari AR, Douma JC, Giller KE, Brouwer ID. Grain legume cultivation and children's dietary diversity in smallholder farming households in rural Ghana and Kenya. Food Sec. 2017;9(5):1053-1071. doi:10.1007/s12571-017-0720-0 
77. Ngema PZ, Sibanda M, Musemwa L. Household Food Security Status and Its Determinants in Maphumulo Local Municipality, South Africa. Sustainability. 2018;10(9):3307. doi:10.3390/su100933 $\underline{07}$

78. Ngeno V. Impact of dairy hubs on smallholder welfare: Empirical evidence from Kenya. Agric Food Econ. 2018;6(1). doi:10.1186/s40100-018-0107-3

79. Musemwa L, Ndhleve S, Sibanda M, Zhou L, Muchenje V, Nakin MD V. Implications of livelihood strategies on Household Dietary Diversity in the Eastern Cape Province of South Africa. JHE. 2018;61(1-3):31-43. doi:10.31901/24566608.2018/6 $\underline{1.1-3.3116}$

80. Valbuena D, Groot JCJ, Mukalama J, Gérard B, Tittonell P. Improving rural livelihoods as a "moving target": Trajectories of change in smallholder farming systems of Western Kenya. Reg Environ Change. 2015;15(7):1395-1407. doi:10.1007/s10113-014-070 $\underline{2-0}$

81. Teucher M, Hornetz B, Jätzold R. Increasing livelihood through use of adapted crop varieties-case study from a semiarid region of East Kenya. Agroecol Sustain FOOD Syst. 2016;40(6):614-632. doi:10.1080/2 $\underline{1683565.2016 .1159265}$

82. Ng'endo M, Bhagwat S, Keding GB, et al. Influence of Seasonal On-Farm Diversity on Dietary Diversity: A Case Study of Smallholder Farming Households in Western Kenya. Ecol Food Nutr. 2016;55(5):403-427. d oi:10.1080/03670244.2016.1200037

83. Njeru PNM, Mugwe J, Maina I, et al. Integrating Farmers and Scientific Methods for Evaluating Climate Change Adaptation Options in Embu County. In: Filho WL, Esilaba AO, Rao KPC, Sridhar G, eds. Adapting African Agriculture to Climate Change: Transforming Rural Livelihoods. Climate Change Management. Springer International Publishing; 2015:185-197. https://doi.org/10.1007/978-3-319-130 $\underline{00-2 \_16}$

84. Trollip K. Irrigation: Irrigation farming: A lifeline for budding "agripreneurs". Water Wheel. 2017;16(1):19-21. https://journals.co.za/content/jour nal/10520/EJC-5656b7028

85. Tchékoté H, Melachio MN, Siyapdje EC. Appropriation foncière, pratiques agricoles et enjeux environnementaux à Bafou-Nord dans les monts Bamboutos (Ouest Cameroun). Belgeo. 2018;(2). doi:1 $\underline{0.4000 / \text { belgeo. } 21085}$
86. Muriithi FK. Land use and land cover (LULC) changes in semi-arid sub-watersheds of Laikipia and Athi River basins, Kenya, as influenced by expanding intensive commercial horticulture. Remote Sens Appl Soc Environ. 2016;3:73-88. doi:10.1016/j.rsase.2016.0 1.002

87. Kurgat BK, Stöber S, Mwonga S, Lotze-Campen H, Rosenstock TS. Livelihood and climate trade-offs in Kenyan peri-urban vegetable production. Agric Syst. 2018;160:79-86. doi:10.1016/j.agsy.2017.10.003

88. Chaminuka P, Udo HMJ, Eilers KCHAM, van der Zijpp A. Livelihood roles of cattle and prospects for alternative land uses at the wildlife/livestock interface in South Africa. Land use policy. 2014;38:80-90. doi:10.1016/i.landusepol.2013.10.007

89. Musinguzi P, Bosselmann AS, Pouliot M. Livelihoods-conservation initiatives: Evidence of socio-economic impacts from organic honey production in Mwingi, Eastern Kenya. For POLICY Econ. 2018;97:132-145. doi:10.1016/i.forpol.2018.09.0 10

90. Jin M, Iannotti LL. Livestock production, animal source food intake, and young child growth: The role of gender for ensuring nutrition impacts. Soc Sci Med. 2014;105:16-21. doi:10.1016/j.socscimed.2014.01.001

91. Nathenson P, Slater S, Higdon P, Aldinger C, Ostheimer E. No sex for fish: Empowering women to promote health and economic opportunity in a localized place in Kenya. Health Promot Int. 2016;32(5):800-807. doi:10.1093/heapro/daw012

92. Nchinda VP, Villano RA, Hadley D, Morales EL. Performance of smallholder minisett seed yam farm enterprises in Cameroon. AFRICAN J Agric Resour Econ. 2016;11(4):277-291. https://ageconsearch.um n.edu/record/252458/? $\ln =$ en

93. Gcumisa ST, Oguttu JW, Masafu MM. Pig farming in rural South Africa: A case study of uThukela District in KwaZulu-Natal. Indian J Anim Res. 2016;50(4):614-620. doi:10.18805/ijar.11175

94. Djoukeng HG, Tankou CM, Degré A. Pollution and siltation of rivers in the western highlands of Cameroon: A consequence of farmland erosion by runoff. In: 21st Century Watershed Technology Conference and Workshop 2014: Improving Water Quality and the Environment. American Society of Agricultural and Biological Engineers; 2014:95-101. d oi:10.13031/wtcw.2014-012

95. Okello JJ, Zhou Y, Kwikiriza N, et al. Productivity and food security effects of using of certified seed potato: The case of Kenya's potato farmers. Agric Food Secur. 2017;6(1). doi:10.1186/s40066-017-010 $\underline{1-0}$ 
96. Adamtey N, Musyoka MW, Zundel C, et al. Productivity, profitability and partial nutrient balance in maize-based conventional and organic farming systems in Kenya. Agric Ecosyst Environ.

2016;235:61-79. doi:10.1016/j.agee.2016.10.001

97. Fiorella KJ, Milner EM, Bukusi E, Fernald LCH. Quantity and species of fish consumed shape breastmilk fatty acid concentrations around Lake Victoria, Kenya. Public Health Nutr. 2018;21(4):777-784. doi:1 $\underline{0.1017 / \mathrm{s} 1368980017003147}$

98. Gallaher CM. Regreening Kibera: How Urban Agriculture Changed the Physical and Social Environment of a Large Slum in Kenya. In: WinklerPrins AMGA, ed. Global Urban Agriculture: Convergence Of Theory And Practice Between North And South. Springer Science and Business Media LLC; 2017:171-183. https://doi.org/10.1007/s10460-013-94 25-y

99. Tsotetsi-Khambule AM, Njiro S, Katsande TC, Harrison LJS. Risk factors associated with taeniosiscysticercosis in rural farming communities in Gauteng Province, South Africa. Trop Anim Health Prod. 2018;50(8):1951-1955. doi:10.1007/s11250-01 $\underline{8-1627-2}$

100. Betek CKE, Jumbam ND. Small scale vegetable production: A case study of Port St Johns, Eastern Cape Province, South Africa. Trans $R$ Soc South Africa. 2015;70(1):41-45. doi:10.1080/0035919x.2014.985759

101. Gininda PS, Antwi MA, Oladele OI. Smallholder sugarcane farmers' perception of the effect of micro agricultural finance institution of South Africa on livelihood outcomes in Nkomazi local municipality, Mpumalanga Province. Mediterr J Soc Sci.

2014;5(27):1032-1042. doi:10.5901/mjss.2014.v5n27p 1032

102. Mirera DO, Ochiewo J, Munyi F. Social and economic implications of small-scale mud crab (Scylla serrata) aquaculture: The case of organised community groups. Aquac Int. 2014;22(4):1499-1514. doi:10.1007/s10499-014-9762-x

103. Mwongera C, Boyard-Micheau J, Baron C, Leclerc C. Social Process of Adaptation to Environmental Changes: How Eastern African Societies Intervene between Crops and Climate. Weather Clim Soc. 2014;6(3):341-353. doi:10.1175/wcas-d-13-00034.1

104. Mwangi M, Egesa A, Matheri F. Strategies to increase strawberry competitiveness among fruit growers, marketers and consumers in Kenya. In: Desjardins Y, ed. VIII International Strawberry Symposium. Vol 1156. Acta Horticulturae.

International Society for Horticultural Science (ISHS); 2017:921-927. https://doi.org/10.17660/actahortic.20 $\underline{17.1156 .136}$
105. Rankoana SA. Subsistence Food Production Practices: An Approach to Food Security and Good Health. Int J Environ Res Public Health. 2017;14(10):1184. doi:10.3390/ijerph14101184

106. Louw A, Jordaan D. Supply chain risks and smallholder fresh produce farmers in the Gauteng province of South Africa. South AFRICAN Bus Rev. 2016;20(1):286-312. doi:10.25159/1998-8125/6051

107. Chaplot V, Abdalla K, Alexis M, et al. Surface organic carbon enrichment to explain greater $\mathrm{CO} 2$ emissions from short-term no-tilled soils. Agric Ecosyst Environ. 2015;203:110-118. doi:10.1016/i.age e.2015.02.001

108. Efole Ewoukem T, Mikolasek O, Aubin J, Tomedi Eyango M, Pouomogne V, Ombredane D. Sustainability of fish pond culture in rural farming systems of Central and Western Cameroon. Int Journal Agricultural Sustainability. 2017;15(2):208-222. doi:1 $\underline{0.1080 / 14735903.2016 .1211243}$

109. Brandt P, Hamunyela E, Herold M, de Bruin S, Verbesselt J, Rufino MC. Sustainable intensification of dairy production can reduce forest disturbance in Kenyan montane forests. Agric Ecosyst Environ. 2018;265:307-319. doi:10.1016/j.agee.2018.06.011

110. Kebede SW, Bokelmann W. Sustainable production of indigenous vegetables for food security: Evidence from HORTINLEA survey in Kenya. In: Axelson LE, Fernqvist F, eds. XVIII International Symposium On Horticultural Economics And Management. Vol 1132. Acta Horticulturae. International Society for Horticultural Science (ISHS); 2016:121-125. https://doi.org/10.17660/actahortic.20 16.1132.16

111. Roberts S, Shackleton C. Temporal Dynamics and Motivations for Urban Community Food Gardens in Medium-Sized Towns of the Eastern Cape, South Africa. Land. 2018;7(4):146. doi:10.3390/land7040146

112. Epule TE, Bryant CR. The adoption of agroecology and conventional farming techniques varies with socio-demographic characteristics of small-scale farmers in the Fako and Meme divisions of Cameroon. GeoJournal. 2016;82(6):1145-1164. do i:10.1007/s10708-016-9734-y

113. Obiero KO, Abila RO, Njiru MJ, et al. The challenges of management: Recent experiences in implementing fisheries co-management in Lake Victoria, Kenya. Lakes Reserv Res Manag. 2015;20(3):139-154. doi:10.1111/1re.12095

114. Brandt P, Herold M, Rufino MC. The contribution of sectoral climate change mitigation options to national targets: A quantitative assessment of dairy production in Kenya. Environ Res Lett. 2018;13(3):034016. doi:10.1088/1748-9326/aaac84 
115. Aliber M, Mdoda L. The Direct And Indirect Economic Contribution Of Small-Scale Black Agriculture In South Africa. Agrekon. 2015;54(2):18-37. doi:10.1080/03031853.2015.106518 $\underline{7}$

116. Oldewage-Theron W, Egal A. The effect of a combination of nutrition education, soy and vegetable gardening, and food preparation skill training interventions on dietary intake and diversity in women: A case study from Qwa-Qwa. South African J Clin Nutr. 2015;28(3):113-120. doi:10.1080/1607065 $\underline{8.2015 .11734545}$

117. Bahta BT, Owusu-Sekyere E, Emmanuel D, Elizabeth TB. The impact of the homestead food garden programme on food security in South Africa. Food Secur. 2018;10(1):95-110. doi:10.1007/s12571-0 17-0756-1

118. Olivier DW, Heinecken L. The personal and social benefits of urban agriculture experienced by cultivators on the Cape Flats. Dev South Afr. 2016;34(2):168-181. doi:10.1080/0376835x.2016.1259 $\underline{988}$

119. Nyaruai MA, Musingi JK, Wambua BN. The potential of agroforestry as an adaptation strategy to mitigate the impacts of climate change: A case study of Kiine Community, Kenya. Nusant Biosci. 2018;10(3):170-177. doi:10.13057/nusbiosci/n100307

120. Omondi SO, Oluoch-Kosura W, Jirström M. The role of urban-based agriculture on food security: Kenyan case studies. Geogr Res. 2017;55(2):231-241. $\underline{\mathrm{d}}$ oi:10.1111/1745-5871.12234

121. Duggan GL, Green LJF, Jarre A. 'Thinking like a fish': Adaptive strategies for coping with vulnerability and variability emerging from a relational engagement with Kob. Marit Stud. 2014;13(1):1-21. $\underline{\mathrm{d}}$ oi:10.1186/2212-9790-13-4

122. Gomes I, Erzini K, McClanahan TR. Trap modification opens new gates to achieve sustainable coral reef fisheries. Aquat Conserv Freshw Ecosyst. 2014;24(5):680-695. doi:10.1002/aqc.2389

123. Wamari JO, Macharia JMK, Sijali I V. Using farmer-prioritized vertisol management options for enhanced green gram and tomato production in Central Kenya. African J Food, Agric Nutr Dev. 2016;16(4):11415-11431. doi:10.18697/ajfand.76.1554 $\underline{0}$
124. Mutemi M, Njenga M, Lamond G, et al. Using local knowledge to understand challenges and opportunities for enhancing agricultural productivity in Western Kenya. In: Oborn I, Vanlauwe B, Phillips M, Thomas R, Brooijmans W, AttaKrah K, eds. Sustainable Intensification In Smallholder Agriculture: An Integrated Systems Research Approach. Earthscan Food and Agriculture Series. Routledge; 2017:177-195. https://doi.org/10.4324/978131561879 1-12

125. Wenhold F, Faber M. Vitamin A-Related Potential of Wild Edible Plants In A School Vegetable Garden: A Case Study From North-West Province, South Africa. J Fam Ecol Consum Sci. 2017;(2):1-12. ht tps://www.ajol.info/index.php/ifecs/article/view/1530 $\underline{81}$

126. Chakona G, Shackleton CM. Voices of the hungry: A qualitative measure of household food access and food insecurity in South Africa. Agric Food Secur. 2017;6(1). https://.doi.org\%2F10.1186\%2Fs400 66-017-0149-X

127. Tshwene C, Oladele I. Water use productivity and food security among smallholder homestead food gardening and irrigation crop farmers in North West province, South Africa. J Agric Environ Int Dev. 2016;110(1):73-86. doi:10.12895/jaeid.20161.399

128. Henschel JR, Lubin Y. Web spider abundance is affected by sheep farming in the Karoo. African $J$ Range Forage Sci. 2018;35(3-4):319-324. https://doi.or g/

129. Maziya M, Mudhara M, Chitja J. What factors determine household food security among smallholder farmers? Insights from Msinga, KwaZuluNatal, South Africa. Agrekon. 2017;56(1):40-52. doi:1 $\underline{0.1080 / 03031853.2017 .1283240}$

130. de la Hey M, Beinart W. Why Have South African Smallholders Largely Abandoned Arable Production in Fields? A Case Study. J South Afr Stud. 2017;43(4):753-770. doi:10.1080/03057070.2016.1265 $\underline{336}$

131. Diiro GM, Seymour G, Kassie M, Muricho G, Muriithi BW. Women's empowerment in agriculture and agricultural productivity: Evidence from rural maize farmer households in western Kenya. Zereyesus Y, ed. PLoS ONE. 2018;13(5):e0197995. doi:10.1371/jo urnal.pone.0197995

132. International Panel of Experts on Sustainable Food Systems (IPES). The new science of sustainable food systems: Overcoming barriers to food system reform. Published online 2015. Accessed February 1, 2021. http://ipes-food.org/img/upload/files/NewScie nceofSusFood.pdf 
133. Nicholson CF, Kopainsky B, Stephens EC, et al. Conceptual frameworks linking agriculture and food security. Nat Food. 2020;1(9):541-551. doi:10.1038/s4 3016-020-00142-3 


\section{SUPPLEMENTARY MATERIALS}

\section{Online Supplementary Document}

Download: https://www.joghr.org/article/19468-a-systematic-scoping-review-of-the-impacts-of-community-foodproduction-initiatives-in-kenya-cameroon-and-south-africa/attachment/54409.docx 